\title{
PENGARUH KEPERCAYAAN KONSUMEN TERHADAP DEVELOPER DALAM PELAKSANAAN PERJANJIAN PENGADAAN PERUMAHAN
}

\author{
HELFIRA CITRA, SRY WAHYUNI, YULIA RISA \\ helfira.citra@gmail.com, sryunidha@gmail.com, yuliarisa24@gmail.com \\ Program Studi Ilmu Hukum Universitas Dharma Andalas
}

\begin{abstract}
Consumers often become parties who are positioned as the less powerful, where legal protection for them is so weak and not guaranteed as expected. Indonesia is a developing country that continues to carry out development in all fields, both in the material and spiritual fields, where the development is aimed at realizing the goal of building a just and prosperous society, one of the developments in the material field is to include facilities and infrastructure such as luxury housing developments, medium, even to housing for people (subsidized). Housing or settlements can create a conducive business climate to be able to open a comfortable settlement. The business offer of a house by the developer is sometimes so diverse that the understanding it conveys is not appropriate or not understood (missunderstanding information), meanwhile the prospective buyer sometimes has agreed to even sign his agreement on the binding purchase agreement (PPJB) with the developer so that it has sometimes even arrived at contract stage at a banking institution. This fact further strengthens the high need for housing, even though the realization of the desire to own a residence does not mean that it will always run smoothly
\end{abstract}

Keywords : Agreements, credit agreements, procurement of housing

Abstrak: Konsumen seringkali menjadi pihak yang jarang diperhatikan kepentingannya, dimana bentuk bantuan hukum begitu lemah dan tidak terjamin sebagaimana yang diharapkan. Indonesia merupakan negara berkembang yang terus melakukan pembangunan disegala bidang, baik dibidang materil maupun dibidang spiritual, dimana pembangunan tersebut bertujuan mewujudkan tujuan pembangunan masyarakat yang adil dan makmur, salah satu pembangunan dalam bidang materil adalah meliputi sarana dan prasarana seperti pembangunan perumahan baik yang berskala mewah, menengah, bahkan sampai kepada perumahan untuk rakyat (bersubsidi). Dalam penelitian ini yang menjadi masalah adalah bagaimana pihak developer menyelesaikan kewajibannya terhadap konsumen yang telah melakukan pembayaran. Metode Pendekatan ini digunakan untuk mengetahui bagaimana gambaran pelaksanaan secara menyeluruh, lengkap, dan sistematis dalam mediasi perbankan. Sedangkan sifat penelitian yang digunakan dalam penulisan ini bersifat deskriptif, yaitu dengan cara menarik kesimpulan dari suatu permasalahan yang bersifat umum terhadap permasalahan konkret yang sedang dihadapi, selanjutnya bahan hukum yang ada dianalisis untuk melihat apakah dapat menjawab permasalahan yang dikemukakan dengan memberikan gambaran secara keseluruhan.

Kata Kunci: Perjanjian, perjanjian kredit, pengadaan perumahan

\section{A. Pendahuluan}

Pengadaan tempat hunian/tempat tinggal (permukiman) adalah usaha pemenuhan keinginan dasar sebagai makhluk sosial, serta guna memperbaiki kualitas hidup, memberikan arahan di sektor regional, menambah peluang pekerjaan dan mengembangkan perekonomian juga dapat meningkatkan pemerataan kesejahteraan rakyat. (Triyuly et al., 2013) Tempat hunian/tempat tinggal atau permukiman ada E-ISSN: 2657-0300 Lembaga Penelitian dan Penerbitan Hasil Penelitian Ensiklopedia 111 
dalam penjelasan Undang-undang Dasar 1945 pasal 28 ayat 1 bahwa setiap orang berhak hidup sejahtera lahir maupun batin, mempunyai sebuah hunian (rumah), dan mendapatkan lingkungan hidup yang baik dan sehat karena merupakan kebutuhan dasar manusia. Pembangunan perumahan dan permukiman tersebut diatur oleh pemerintah dalam suatu Undang-undang Nomor 1 Tahun 2011 Tentang Perumahan dan permukiman yang dimaksudkan guna memberi arahan dalam pembangunan perumahan serta permukiman. Dengan perekonomian yang sudah terbangun terencana diharapkan menciptakan pola hidup bermasyarakat yang berkualitas guna menghasilkan kenyamanan dalam hubungan bermasyarakat.

Rumah dan kelengkapannya merupakan salah satu kebutuhan pokok manusia. Tidak sedikit rumah dijadikan sebagai indikator keberhasilan seseorang dan sebagai asset pengembangan usaha dan peningkatan nilai ekonomi pemiliknya. Tingginya intensitas pembangunan, jumlah penduduk yang meningkat, harga rumah yang mahal dan tanah yang merupakan sumber daya yang tidak dapat diperbaharui membuat masyarakat berekonomi lemah tidak dapat menjangkau rumah layak huni.

Indonesia berada dalam tahap Pembangunan di segala bidang antara lain meliputi bidang sarana dan prasarana yang berwujud pembangunan dan rehabilitasi jalan, jembatan, perumahan rakyat, gedung-gedung perkantoran, dan fasilitas umum. Sedangkan pembangunan dibidang spiritual meliputi pembangunan pemerintahan dibidang pendidikan, agama, sosial, budaya, dan politik. Pemerintah selalu mengusahakan pembangunan tersebut agar dapat dilakukan dengan cara optimal, baik dengan pembangunan jangka pendek, jangka menengah, maupun jangka panjang. Keinginan terhadap sebuah hunian adalah capaian seseorang (personal) dimana seutuhnya jadi prioritas personal masing-masing tersebut, ada kalangan mungkin menilai bahwa kurang lengkap kualitas hidup seorang manusia jika tidak mempunyai hunian atau kediaman pribadi. Dengan demukian, hunian atau rumah tersebut bukan sekadar tempat berteduh, melainkan semua orang ingin tempat hunian/rumah mereka memiliki unsur kenyamanan dan keamanan, adanya berbagai fasilitas umum dan sosial hingga sarana dan prasarana memadai. Yang menjadi kendala bagi setiap individu disini adalah keterbatasan untuk mendapatkan perumahan yang ideal. Dengan demikian pembahasan mengenai hunian/permukiman ini menjadi perhatian kedua belah pihak tidak saja dominasi individu tersebut.

Memang sudah terdapat political will dari pemerintah guna menyediakan perumahan terutama yang ditujukan untuk masyarakat berekonomi menengah kebawah, melalui pembangunan perumahan oleh perum perumnas. Walaupun demikian laju keinginan masyarakat akan perumahan jauh melebihi kemampuan pemerintah. Melihat adanya kesempatan seperti ini, maka pihak pengembang (developer) swasta bertumbuh dan berkembang hingga menjamur dan melihat prospek pengadaan perumahan ini sebagai pasar yang potensial untuk memperoleh profit.

\section{B. Metodologi Penelitian}

Adapun metode yang akan digunakan dalam tulisan ini adalah pendekatan yuridis sosiologis atau empiris. Metode Pendekatan ini digunakan untuk mengetahui bagaimana gambaran pelaksanaan secara menyeluruh, lengkap, dan sistematis dalam mediasi perbankan. Sedangkan sifat artikel yang digunakan dalam penulisan ini bersifat deduktif, yaitu dengan cara menarik kesimpulan dari suatu permasalahan yang bersifat umum terhadap permasalahan konkret yang sedang dihadapi, selanjutnya 
bahan hukum yang ada dianalisis untuk melihat apakah dapat menjawab permasalahan yang dikemukakan atau memberikan gambaran secara umum mengenai pembangunan perumahan oleh developer di daerah baring ini serta kendala yag dihadapi baik oleh developer terutama oleh konsumen.

\section{Hasil dan Pembahasan}

\section{Tinjauan Umum Mengenai Perjanjian}

Pembahasan mengenai perjanjian ini kiranya tidak dapat dilepaskan dari pembahasan mengenai perikatan, hal tersebut disebabkan bahwa keduanya mempunyai hubungan atau kaitan yang erat, dimana perjanjian merupakan salah satu sumber atau yang menjadi penyebab lahirnya perikatan disamping sumber lainnya yakni undangundang. Jika kita berbicara mengenai perjanjian dalam aspek hukum maka peraturan yang berlaku bagi perjanjian diatur dalam buku ketiga KUHPerdata mengenai "Perikatan". Dalam buku ketiga tersebut ketentuan mengenai perjanjian terdapat dalam bab kedua. Perjanjian diatur dalam buku ketiga KUHPerdata karena perjanjian merupakan salah satu sumber dari perikatan.

Pengertian perjanjian menurut pasal 1313 KUHPerdata dinyatakan bahwa suatu perjanjian adalah "Suatu perbuatan dimana satu orang atau lebih mengikatkan dirinya terhadap satu orang atau lebih". Namun demikian rumusan Pasal 1313 KUHPerdata tersebut tampaknya kurang lengkap karena yang mengikatkan diri dalam perjanjian hanya salah satu pihak saja padahal yang seringkali dijumpai adalah perjanjian dimana kedua belah pihak saling mengikatkan diri satu sama lain, para pihak saling mengikatkan diri sehingga mempunyai hak dan kewajiban yang bertimbal balik, oleh sebab itu rumusan dalam pasal tersebut seharusnya ditambah "atau saling mengikatkan dirinya satu sama lain”.

Bahwa perjanjian jika tidak memenuhi prestasi yang telah dijanjikan sehingga menurut hukum perjanjian tersebut dianggap sebagai perjanjian yang menimbulkan risiko.(Bank et al., 2006) Sejalan dengan berkembangnya peradaban kehidupan umat manusia dewasa ini turut menggiring terjadinya perubahan perilaku dan berhubungan satu sama lain. Hal tersebut berpengaruh terhadap usaha yang telah menjadi bagian dari hidup manusia yang semakin lama semakin berkembang pesat. Hal tersebut merupakan hal yang sejatinya tidak terpikirkan oleh manusia, akan tetapi seiring dengan perkembangan zaman menyebabkan hal tersebut menjadi terwujud.

\section{Asas-asas dalam Perjanjian}

Asas-asas dalam hukum perjanjian sangatlah perlu dikaji untuk lebih mudah memahami berbagai ketentuan undang-undang mengenai sahnya suatu perjanjian. Adapun asas yang dikenal dalam hukum perjanjian di Indonesia diantaranya (Nico Pratama, 2015):

a) Asas Konsensualisme (Kesepakatan). Yaitu suatu persesuaian kehendak yang menyangkut saat lahirnya suatu perjanjian. Ini berarti bahwa untuk melahirkan suatu perjanjian cukup dengan dicapainya kata sepakat mengenai hal-hal yang pokok dari perjanjian tersebut.

b) Asas Kebebasan Berkontrak, Asas ini tertuju pada isi perjanjian dimana asas ini mengandung maksud untuk memberikan kebebasan kepada setiap orang untuk membuat perjanjian mengenai apasaja asalkan perjanjian yang dibuat tersebut disebabkan sesuatu yang halal.

c) Asas Kekuatan Mengikat, Perjanjian mempunyai kekuatan mengikat sebagai suatu undang-undang bagi para pihak yang mengadakannya, hal ini berarti bahwa

E-ISSN: 2657-0300 Lembaga Penelitian dan Penerbitan Hasil Penelitian Ensiklopedia 113 
para pihak yang mengadakan perjanjian tidak dapat melepaskan diri secara sepihak terhadap perjanjian yang bersangkutan tanpa adanya kesepakatan dari pihak lainnya.

d) Asas Itikad Baik (Kepercayaan), Asas ini tertuju pada pelaksanaan dari perjanjian yang diadakan para pihak, asas ini mengandung makna bahwa pelaksanaan perjanjian harus berjalan diatas jalur yang benar.

\section{Tinjauan Umum mengenai Perjanjian Kredit}

Perjanjian kredit merupakan perjanjian konsensuil antara debitur dengan kreditur (dalam hal ini bank) yang melahirkan hubungan tentang piutang, dimana debitur berkewajiban membayar kembali pinjaman yang diberikan oleh kreditur dengan berdasarkan syarat dan kondisi yang telah disepakati oleh para pihak. Dalam buku III KUHPerdata tidak terdapat ketentuan yang khusus mengatur perihal perjanjian kredit, namun dengan berdasarkan atas asas kebebasan berkontrak, para pihak bebas untuk menentukan isi dari perjanjian kredit sepanjang tidak bertentangan dengan UU, ketertiban umum, kesusilaan, dan kepatutan. Dengan disepakati dan ditandatanganinya perjanjian kredit tersebut oleh para pihak, maka sejak itu perjanjian lahir dan mengikat para pihak yang membuatnya dan berlaku sebagai undang-undang. Dilihat dari pembuatannya, suatu perjanjian dapat digolongkan menjadi beberapa macam, diantaranya: Perjanjian kredit dibawah tangan Yaitu perjanjian kredit yang dibuat dalam bentuk tertulis di bawah tangan (Satria; \& Setiani, 2018), dilakukan oleh dan antara para pihak yang terlibat dalam perjanjian kredit tersebut tanpa melibatkan pihak pejabat yang berwenang (notaris). Suatu perjanjian kredit pada umumnya terdiri dari judul/kepala dan komparisi (bagian dari perjanjian kredit yang memuat keterangan identitas para pihak) diantaranya premis (yang berisi uraian yang memuat alasanalasan atau dasar pertimbangan para pihak dalam membuat perjanjian kredit atau pokok-pokok pikiran yang merupakan fakta-fakta secara singkat yang menggerakkan para pihak untuk mengadakan perjanjian, batang tubuh (berisikan hal-hal yang disetujui para pihak berupa klausula baik klausula hukum maupun klausula komersial yang berkaitan dengan pemberian fasilitas kredit), dan kolom tanda tangan/signature page (berisikan tanda tangan para pihak pembuat perjanjian).

Pada dasarnya isi klausula yang tercantum dalam perjanjian kredit dapat digolongkan menjadi Klausula hukum, adalah klausula yang berisikan ketentuanketentuan hukum yang biasanya berlaku untuk pemberian fasilitas kredit. Dengan berlakunya Undang-undang nomor 8 Tahun 1999 tertanggal 20 April 1999 tentang perlindungan konsumen (UUPK) maka dalam isi perjanjian kredit harus pula memenuhi ketentuan ketentuan dalam UUPK, seperti mengenai pencantuman klausula baku, dimana dalam pasal 18 ayat (1) UUPK menyebutkan bahwa dalam perjanjian kredit dilarang mencantumkan klausula baku. Berdasar atas tujuan yang ingin dicapai oleh para pihak serta kebutuhan adanya aturan yang mampu mengkoordinir kepentingan serta memberikan perlindungan bagi para pelaku ekonomi, maka dalam perkembangannya berdampak pada bentuk perjanjian kredit yang efektif dan tidak membutuhkan waktu lama dalam asas kebebasan berkontrak (Satria; \& Setiani, 2018).

Pada dasarnya isi klausula yang tercantum dalam perjanjian kredit pengadaan perumahan ini dapat digolongkan menjadi Klausula hukum, klausula hukum adalah klausula yang berisikan ketentuan-ketentuan hukum yang biasanya berlaku untuk pemberian fasilitas kredit. Termasuk dalam klausula ini antara lain klausula 
perlindungan bank, pernyataan dan jaminan, dan lain-lain. Adapun fasilitas klausula kredit diantaranya adalah: 1) Jenis, jumlah, dan jangka waktu fasilitas; 2) Perubahan mata uang pinjaman (berlaku untuk pinjaman Non-rupiah); 3) Penarikan fasilitas kredit; 4) Pembuktian hutang; 5) Cara pembayaran kembali; 6) Bunga; 7) Komisi dan fee; 8) Bunga denda; dan 9) Pembukuan (lokasi dimana bank akan membukukan pinjaman tersebut).

Dengan berlakunya Undang-undang nomor 8 Tahun 1999 tertanggal 20 April 1999 tentang perlindungan konsumen (UUPK) maka dalam isi perjanjian kredit harus pula memenuhi ketentuan ketentuan dalam UUPK, seperti mengenai pencantuman klausula baku, dimana dalam pasal 18 ayat (1) UUPK menyebutkan bahwa dalam perjanjian kredit dilarang mencantumkan klausula baku, diantaranya: 1) Menyatakan tunduknya konsumen kepada peraturan yang berupa aturan baru, tambahan, lanjutan dan atau pengubahan lanjutan yang dibuat secara sepihak oleh pelaku usaha dalam masa konsumen memanfaatkan jasa yang dibelinya; dan 2) Menyatakan bahwa konsumen memberi kuasa kepada pelaku usaha pembebanan hak tanggungan, hak gadai, atau hak jaminan terhadap barang yang dibeli oleh konsumen secara angsuran.

\section{Hubungan Akta Pengakuan Hutang dengan Perjanjian Kredit}

Bahwa sebuah perjanjian kredit tidak akan dapat dibuat dalam bentuk pengakuan hutang. Akta pengakuan hutang haruslah murni, dibuat tersendiri dan tidak boleh dimasukkan ketentuan-ketentuan dalam perjanjian kredit. Apabila suatu akta pengakuan hutang di campur adukkan dengan ketentuan-ketentuan dan syarat-syarat dalam dalam perjanjian kredit seperti suku bunga, penalty (denda), pengakhiran jangka waktu pinjaman dan sebagainya akta tersebut kehilangan executorial kracht dan menjadikannya sebagai grosse akta yang non executorial.

Rumah merupakan salah satu kebutuhan manusia yang berfungsi sebagai hunian atau tempat tinggal dan sarana pembinaan keluarga. Tidak sedikit rumah dijadikan sebuah indikator dalam mencapai keberhasilan seseorang (Handayani Hutapea dan Ir.Djoko Suwandono, M. 2014). Merupakan salah satu kebutuhan dasar manusia selain kebutuhan sandang, pangan, layanan kesehatan dan pendidikan. Rumah merupakan sarana memanusiakan manusia, pemberi ketentraman hidup dan sebagai pusat kegiatan berbudaya manusia dan juga memiliki rumah merupakan memiliki investasi jangka panjang.

Memenuhi kebutuhan rumah yang dilakukan pemerintah adalah dalam rangka peningkatan dan pemerataan kesejahteraan rakyat. Sebagai kebutuhuan dasar manusia rumah merupakan syarat untuk memperoleh kesejahteraan, bahkan sebagai tolok ukur sebuah kesejahteraan. Perumahan adalah sekelompok rumah yang telah dilengkapi dengan sarana dan prasarana, bila telah dapat menunjang kehidupan dan perikehidupan manusia maka sudah bisa dikatakan sebagai sebuah permukiman(Perumahan \& Permukiman, 2007). Dengan demikian rumah sudah menjadi kebutuhan dasar seluruh manusia untuk membina keluarga dalam rangka menjaga keberlangsungan hidupnya. Dari seluruh manusia yang membutuhkan rumah terdapat kelompok yang memiliki kesulitan cukup besar dalam memenuhi kebutuhan perumahannya, dan kelompok tersebut adalah kelompok yang berpenghasilan rendah (Lestari, 2017).

Menurut Asian Development Bank (ADP) masyarakat berpenghasilan rendah adalah masyarakat yang tidak memiliki akses dalam menentukan keputusan yang menyangkut dengan kehidupan mereka, secara sosial mereka akan tersingkir dari institusi yang bernama masyarakat, rendahnya kualitas hidup, buruknya etos kerja dan 
pola piker serta lemahnya akses mereka terhadap asset lingkungan seperti air bersih dan listrik.

Memenuhi kebutuhan rumah yang dilakukan pemerintah adalah dalam rangka peningkatan dan pemerataan kesejahteraan rakyat. Sebagai kebutuhuan dasar manusia rumah merupakan syarat untuk memperoleh kesejahteraan, bahkan sebagai tolok ukur sebuah kesejahteraan. Perumahan adalah sekelompok rumah yang telah dilengkapi dengan sarana dan prasarana, bila telah dapat menunjang kehidupan dan perikehidupan manusia maka sudah bisa dikatakan sebagai sebuah permukiman. Dengan demikian rumah sudah menjadi kebutuhan dasar seluruh manusia untuk membina keluarga dalam rangka menjaga keberlangsungan hidupnya. Dari seluruh manusia yang membutuhkan rumah terdapat kelompok yang memiliki kesulitan cukup besar dalam memenuhi kebutuhan perumahannya, dan kelompok tersebut adalah kelompok yang berpenghasilan rendah.

Saat ini ketersediaan rumah atau perumahan menjadi permasalahan, disamping tanah dengan harga yang menjadi momok bagi masyarakat dengan segala bangunan yang ada diatasnya. Tanah yang dimaksud dalam hal ini adalah tanah yang tidak dapat diperbanyak dan harus dimaksimalkan pemanfaatannya. Namun dalam pemanfaatannya sering dijadikan sebagai asset oleh spekulan tanah sehingga pemanfaatan tanah hanya untuk kalangan menengah keatas saja. Hal ini dapat dilihat dari harga tanah yang terus meningkat terutama di kawasan kota dan perkotaan.

\section{Penutup}

Adapun kesimpulan dalam penelitian ini adalah bahwa dalam perjanjian ini terdapat dua pihak yakni pihak developer dengan pihak konsumen. Pada pelaksanaan perjanjian antara developer dengan konsumen dalam hal pengadaan perumahan ini termasuk kedalam perjanjian yang tidak main-main karena melibatkan dua orang yang sebelumnya belum saling mengenal dan oleh karena itu kedua belah harus sama-sama berniat dan beritikad baik sehingga tidak memunculkan wanprestasi (pelanggaran) dan tidak terjadi hal-hal diluar dugaan developer dengan konsumen terhadap kedua belah pihak. Pihak developer sebagai pihak penyedia perumahan harus menepati isi perjanjian perihal meliputi bagaimanapun bentuk rumah yang diinginkan konsumen (selama ada dalam klausula perjanjian yang dibuat), perubahan model rumah dan bahan yang digunakan, selama memang tidak berat menambah biaya diluar yang sudah di prediksi pihak konsumen dengan pihak developer. Begitupun halnya jika pembangunan rumah tersebut menurut konsumen menggunakan biaya dibawah prediksi atau perkiraan konsumen, maka pihak konsumen tidak dibenarkan menarik atau meminta kembali dana yang telah disepakati dengan alasan apapun atau bahkan memaksa dana atau sejumlah uang yang telah diserahkan oleh pihak konsumen ke pihak developer. Dan untuk pihak konsumen juga hendaknya tidak mempersulit developer dalam hal pembayaran jika sudah sampai pada waktu yang memang telah disepakati, hendaknya melakukan atau memberikan pembayaran sesuai dengan kesepakatan yang telah disepakati. Jika tidak dibayar tentu sangat wajar jika pembangunan rumah konsumen juga mengalami keterlambatan. Oleh karena itu kedua belah pihak hendaknya saling berkoordinasi dengan baik agar menciptakan suasana kondusif bagi kedua belah pihak, dari pihak konsumen merasa puas sedangkan dari pihak developer juga merasa dipercaya dan semoga saja memberikan pelanggan atau konsumen baru. Adapun kendala dala tinjauan pengadaan perumahan antara developer 
dengan konsumen ini sepertinya bias diminimalisir dengan cara pihak yang telah berjanji hendaknya mencantumkan klausula yang diharapkan sebagai sanksi jika salah satu pihak memutuskan hubungan perjanjian dipertengahan jalan atau bahkan salah satu pihak menghilang begitu saja. Seperti halnya kita ketahui bahwa pengadaan perumahan ini cukup banyak membuat modus bahkan perusahaan yang mereka anggap sebagai naungan developer itu nihil adanya, oleh karena itu sebaiknya ada agunan (jaminan) dari pihak developer terhadap pihak konsumen untuk meyakinkan bahwa mereka bukanlah penipu, karena pengadaan perumahan ini tentu saja dilakukan oleh dua pihak yakni developer dengan konsumen yang mana sebagian besar diantara kedua belah pihak sama sekali belum saling mengenal.

Dalam penelitian ini adapun saran yang ingin penulis berilkan diantaranya yaitu bahwa hendaknya pihak developer tidak melanggar perjanjian yang telah disepakati perihal waktu pembayaran perumahan, karena dalam kenyataannya pihak developer melakukan pelanggaran dalam bentuk penagihan pembayaran pada pihak konsumen jika pihak developer membutuhkan atau terdesak dana. Disamping itu kita ketahui bersama bahwa kasus pengadaan perumahan ini cukuplah banyak dan sangat diprihatinkan karena tentu saja pihak konsumen bahkan telah ada yang mengeluarkan dana yang tidak sedikit misalnya dalam pembayaran uang muka (Don't payment), bahkan seperti kita ketahui pengadaan perumahan ini dominan di minati para keluarga baru yang juga baru memiliki dana untuk pembangunan istana kecil mereka kelak. Jadi untuk mengantisipasi hal yang tidak di inginkan kedua belah pihak terutama disini pihak konsumen maka sebaiknya dalam perjanjian yang dibuat dicantumkan sanksi bagi salah satu pihak yang melakukan wanprestasi dan jika memungkinkan pihak developer memberikan jaminan pada pihak konsumen sebagai bukti bahwa ini dibuat atau dilaksanakan serius sampai perumahan tersebut selesai menurut kedua belah pihak yakni pihak developer dengan pihak konsumen. Sementara itu pihak konsumen hendaknya dapat menjadikan itu pembelajaran agar pembangunan perumahan konsumen yang telah disepakati dapat terselesaikan dengan baik dan sesuai waktu yang disepakati.

\section{Daftar Pustaka}

Triyuly, W., Studi, P., Arsitektur, T., Teknik, F., Sriwijaya, U., Mewah, R., ... Perumahan, P. (2013). Identifikasi Pembangunan Type Rumah. Rekayasa Sriwijaya, 22(1), 1-7

Bank, A., Konsumen, D. D. A. N., Pt, D. I., Niaga, B., Cabang, T., Semarang, A. Y., ... Semarang, A. Y. (2006). Perjanjian Pengadaan Perumahan Antara Bank ,Developer dan konsumen. p. 1-82.

Nico Pratama, A. I. K. P. N. S. (2015). Hukum Kontrak Dalam Perspektif Komparatif (Menyorot Perjanjian Bernama Dengan Perjanjian Tidak Bernama). Serambi Hukum, 8(02), 138-151.

Perumahan, K., \& Permukiman, D. A. N. (2007). Kebijakan Perumahan Dan Permukiman Bagi Masyarakat Urban. Dinamika, 16(1).

Satria; M. R., \& Setiani, T. (2018). Analisis Perbandingan Pemberian Kredit Pemilikan Rumah (KPR) Pada Bank Konvensional Dengan PEMBIAYAAN Murabahah (KPR) Pada Bank Syariah (Studi Kasus Pada Bank BJB dengan Bank BJB Syariah). Amwaluna. Bank, A., Konsumen, D. D. A. N., Pt, D. I., Niaga, B., Cabang, T., Semarang, A. Y., ... Semarang, A. Y. (2006). Perjanjian Pengadaan Perumahan Antara Bank, Developer dan konsumen. p. 1-82.

Handayani Hutapea dan Ir.Djoko Suwandono, M. (2014). New Housing Development 
Planning and Land Acquisition Strategy for Low-Income. Jurnal Ruang, 2(4), 371-380.

Lestari, D. S. S. . D. (2017). ISSN : 2301 - 668X Perkembangan Perumahan dan Permukiman Sebagai Penentu Arah dan Bentuk Kebutuhan Permukiman di Pinggiran Kota Dwi Suci Sri Lestari 1, Djumiko 2. E-Jurnal Teknik Sipil Dan Rsitektur Fakultas Teknik UTP Surakarta, p. 25

Nico Pratama, A. I. K. P. N. S. (2015). Hukum Kontrak Dalam Perspektif Komparatif (Menyorot Perjanjian Bernama Dengan Perjanjian Tidak Bernama). Serambi Hukum, 8(02), 138-151. 